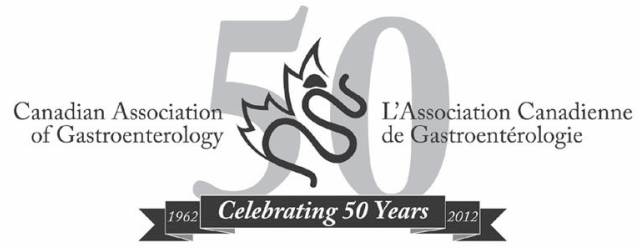

\title{
Canadian Association of Gastroenterology Visiting Research Professorship and the New Canadian Association of Gastroenterology Visiting Clinical Professorship
}

\author{
André G Buret PhD, VP Research Affairs, Craig Render MD, VP Education Affairs
}

\begin{abstract}
CANADIAN ASSOCIATION OF GASTROENTEROLOGY VISITING RESEARCH PROFESSORSHIP

The Canadian Association of Gasgtroenterology (CAG) Visiting Research Professorship is offered annually to a member of CAG who is a proven teacher and an outstanding researcher. The Visiting Research Professor is asked to visit at least six sites (typically academic centers) across the country during the period of July 1 to June 30 . The CAG supports the cost of the air travel for the Visiting Research Professor while the host sites are responsible for costs of local travel, accommodation, meals and any honorarium.
\end{abstract}

Announcing the 2012-2013 CAG Visiting Research Professor Dr Nicola Jones

Dr Nicola Jones received her medical degree from the University of Toronto (Toronto, Ontario) in 1989. She subsequently completed training in pediatrics and pediatric gastroenterology, hepatology and nutrition at The Hospital for Sick Children (SickKids) in Toronto and a $\mathrm{PhD}$ in molecular and medical genetics at the University of Toronto. Dr Jones accepted a faculty position at the hospital as a clinician scientist and pediatric gastroenterologist in 1999, and was promoted to full professor and senior scientist in 2010.

Dr Jones's research program focuses on host pathogen interactions with particular interests in Helicobacter pylori and inflammatory bowel disease. She has had funding from CIHR, CCFC and CAG. Dr Jones is the author of 75 peer-reviewed articles and has received awards from the University of Toronto Department of Pediatrics (Young Investigator Award 2004) and CAG (Young Investigator Award 2005, Young Educator Award 2009). She has given invited lectures both nationally and internationally.

Dr Jones is also passionate about research education and has served as the training program director for the Division of Gastroenterology/ Hepatology and Nutrition at SickKids as well as on the Nucleus Committee for the Royal College of Physicians and Surgeons (Gastroenterology). She currently is the chair of the Clinician Scientist Program at SickKids and the Centre Leader for the University of Toronto Canadian Child Health Clinician Scientist Program. She has chaired numerous meetings for trainees emphasizing career development and research including CAG Gastroenterology Residents in Training (GRIT), NASPGHAN First Year Fellows Conference, and CAG Research Topics in GI Disease.

Dr Jones has served on the CAG Research Committee, the CAG Education Committee, the HDK/EM CIHR panel, and chaired the CCFC Grant review panel. She has also served as a council member for the North American Society of Pediatric Gastroenterology, Hepatology and Nutrition and is currently the VP secretary for the CAG.

\begin{abstract}
Thanks to the 2011-2012 CAG Visiting Research Professor Dr Derek McKay, University of Calgary

The CAG would like to express its sincere appreciation to Dr McKay for being the 2011/2012 CAG Visiting Research Professor. Dr McKay was able to visit six centres during his term (Vancouver, Toronto, Hamilton, Toronto, Kingston and Halifax). This is a remarkable commitment and has certainly fulfilled the intent of the award. Our congratulations and thanks to Dr McKay.
\end{abstract}

\section{CAG VISITING CLINICAL PROFESSORSHIP}

The CAG Visiting Clinical Professorship, introduced in 2012, is offered annually to a member of CAG who is a proven educator and an outstanding clinician with interest in clinical research. The Visiting Clinical Professor will focus his or her visits to that of regional meetings/ events versus academic sites. The recipient of the award is asked to visit at least six centres across Canada during the period of July 1 to June 30. The CAG supports the cost of air travel for the Visiting Clinical Professor while the host sites are responsible for costs of local travel, accommodation, meals and any honorarium.

\section{Announcing the Inaugural CAG Visiting Clinical Professor - Dr David Armstrong}

Dr David Armstrong graduated from Churchill College, Cambridge University and King's College Hospital, London, United Kingdom in 1977. After two years as a family physician in Labrador, he completed his internal medicine and gastroenterology training in the United Kingdom, Switzerland and Canada. He took up a faculty appointment at McMaster University (Hamilton, Ontario) in 1998 and was appointed professor of medicine in 2012.

David Armstrong has been principal investigator on many national and international clinical studies; his clinical and research interests include gastroesophageal reflux disease (GERD), dyspepsia and peptic ulcer disease, inflammatory bowel disease, nutrition, electronic health records, education and practice audit with more than 150 peerreviewed publications, 80 invited articles and 250 peer-reviewed abstracts.

$\mathrm{He}$ is past Chief of Clinical Service for Gastroenterology at Hamilton Health Sciences (2000 to 2007), Medical Director of the Hamilton Health Sciences (HHS) Home Parenteral Nutrition Program and Coordinator of the McMaster IBD Clinic. He has served on the CAG Research and Education Committees, the CAG/CASL GRIT Course Committee (GRIT: 1996 to 2006), the CAG Endoscopy Committee (Lead: 2006 to 2012) and the CAG Quality Program Endoscopy (Lead: 2007 to present). He is regional governor (Ontario)

\section{The CAG is proud to acknowledge its Benefactor Corporate Sponsors:}
Abbott Canada
AstraZeneca Canada Inc
Olympus Canada Inc 
for the American College of Gastroenterology (2009 to present) and associate editor (esophagus) for the American Journal of Gastroenterology (2009 to present). He has received the CAG Educational Excellence Award (2009) and, on behalf of the CAG, the Royal College Accredited CPD Provider Innovation Award (2011).

He has participated in numerous consensus conferences and working groups on dyspepsia, GERD, irritable bowel syndrome, Helicobacter pylori, endoscopy credentialing, colonoscopy standards and he chaired the CAG Consensus Conferences on GERD (2004), and Endoscopy Quality \& Safety Indicators (2010).

Dr Armstrong has given more than 350 invited presentations and has organized numerous workshops, including the annual Canadian first year gastroenterology residents' endoscopy educational course, at McMaster University (2007 to present), in addition to many other accredited educational events.
If you are interested in having Dr Jones or Dr Armstrong visit your centre during their term, please contact the CAG National Office at general@cag-acg.org.

Nominations for these awards can be made by any member of the CAG. To nominate a candidate please complete the Nomination Form for these awards found on the CAG website at www.cag-acg.org under 'Recent Listings'. A curriculum vitae must be concurrently forwarded to the CAG National Office, preferably in electronic format. The CAG Research Committee will review the nominations for the Visiting Research Professor and the CAG Education Committee will review the nominations for the Visiting Clinical Professor, each will make recommendations to the CAG Board, who will make the final decision on the recipients. Nominations for these awards must be received by July 31, 2012 . 


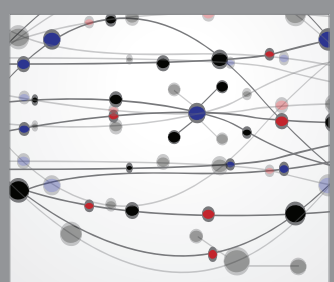

The Scientific World Journal
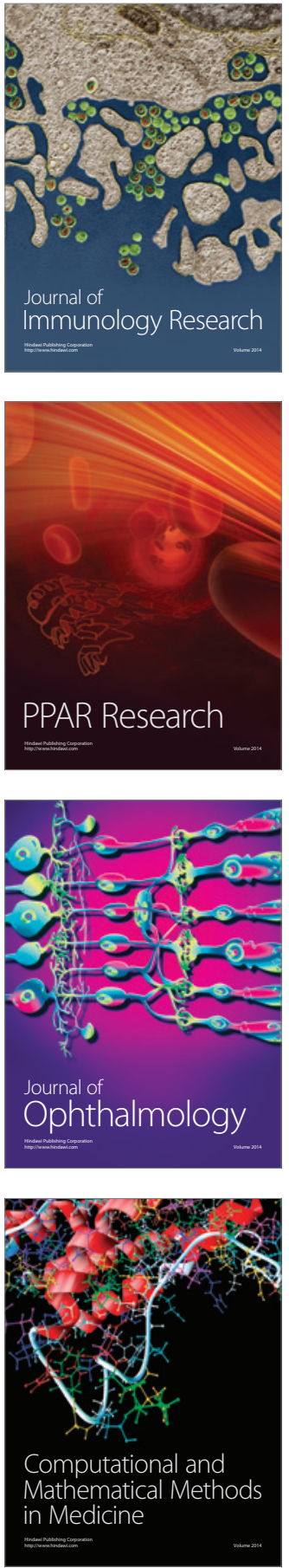

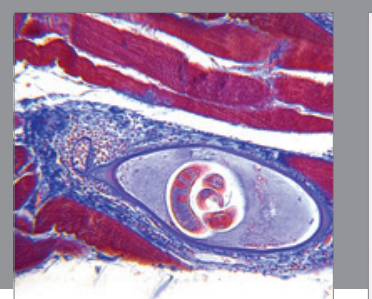

Gastroenterology Research and Practice

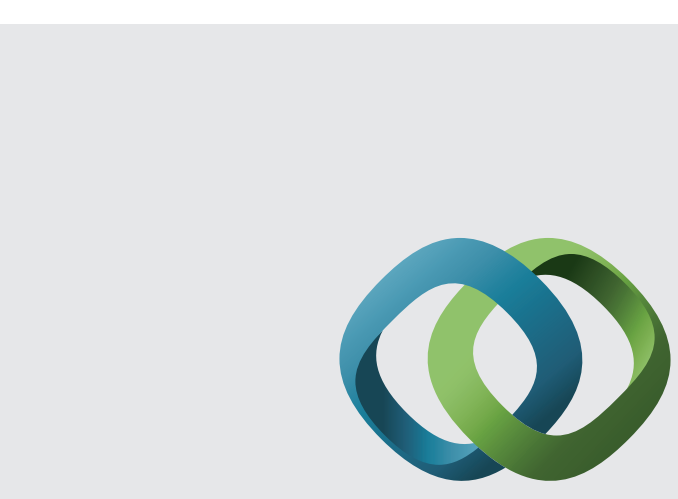

\section{Hindawi}

Submit your manuscripts at

http://www.hindawi.com
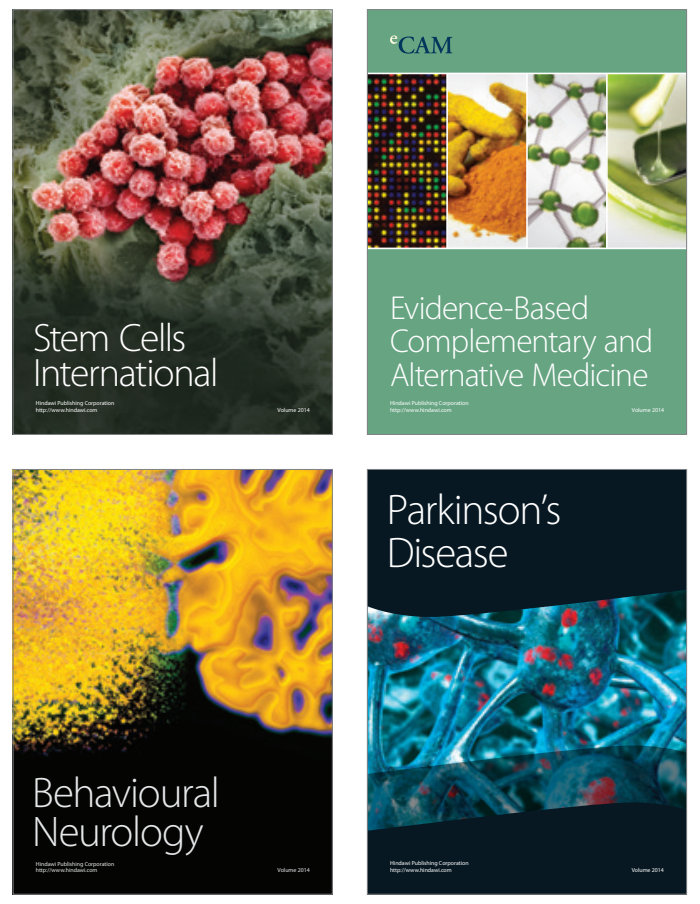
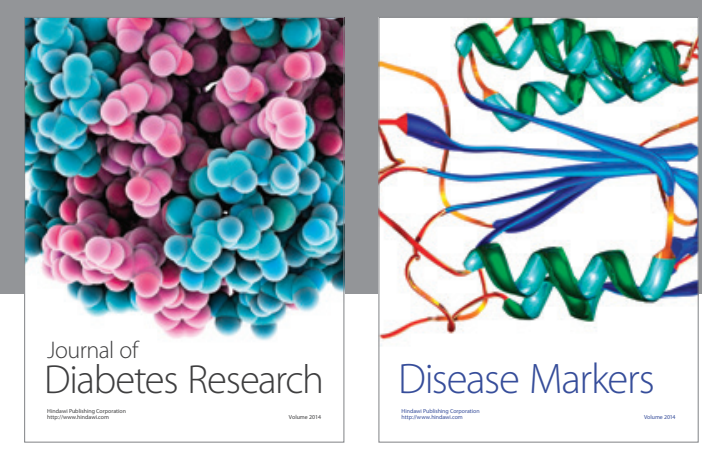

Disease Markers
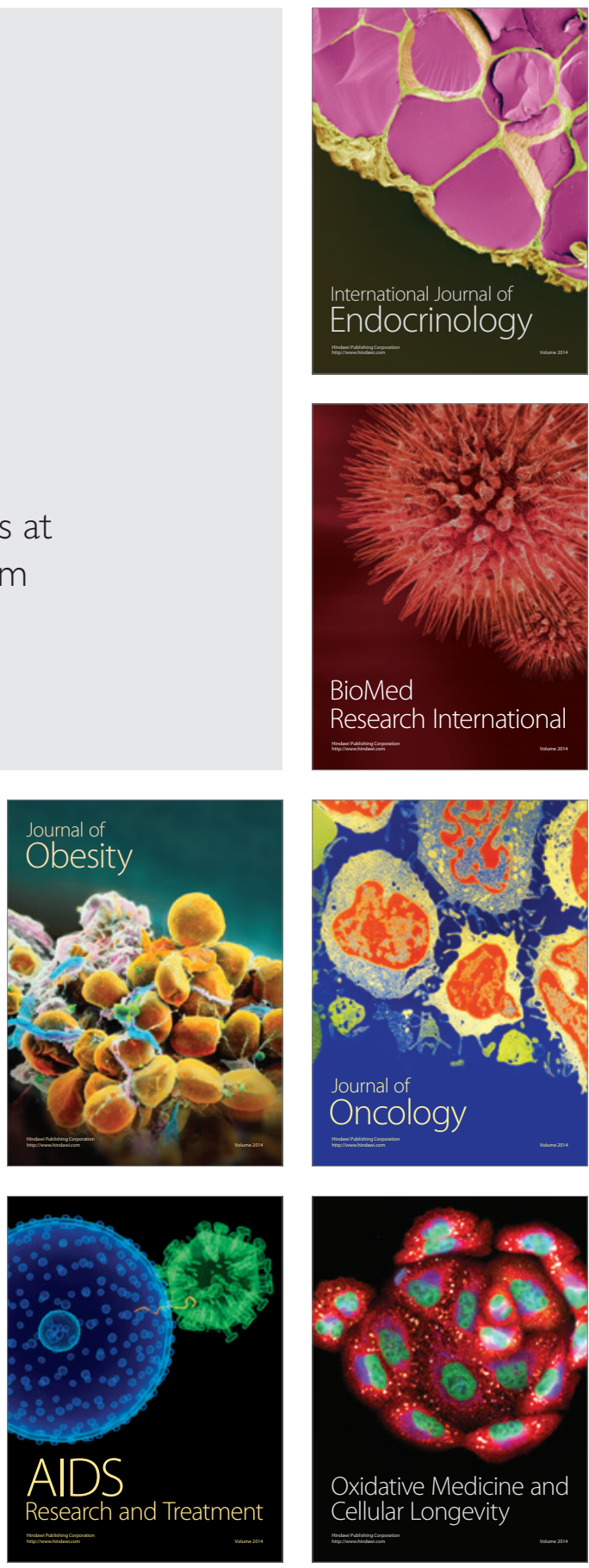